\title{
Effects of viral enrichment on the mortality and growth of heterotrophic bacterioplankton
}

\author{
Rachel T. Noble ${ }^{1, *}$, Mathias Middelboe ${ }^{2}$, Jed A. Fuhrman ${ }^{1}$
}

${ }^{1}$ University of Southern California, AHF 107, University Park, Los Angeles, California 90089-0371, USA
${ }^{2}$ Marine Biological Laboratory, University of Copenhagen, Strandpromenaden 5, DK-3000 Helsingør, Denmark

\begin{abstract}
The direct effects of viral enrichments upon natural populations of marine viruses and bacteria were studied in seawater from Santa Monica Bay, CA, USA. Active virus concentrates, or control additions (ultrafiltered seawater or autoclaved virus concentrate) were added to $2 \downarrow$ incubations of protist-free seawater, and the effects were monitored for about $3 \mathrm{~d}$. At the beginning of the experiments, the virus numbers reflected the expected addition of intact virus particles as determined by transmission electron microscopy (TEM). Subsequently, the mean frequency of visibly infected bacteria (FVIB; \% bacteria which were visibly infected with 5 or more virus-like particles) was greater in the enriched incubations than in the controls. In controls, the estimated percent of bacteria that were infected remained constant at about 5 to $10 \%$ of the total bacterial population, but with active enrichment, 10 to $35 \%$ of the total bacterial population was infected at a given time. Therefore, by increasing the concentration of active viruses in seawater incubations we were able to increase the amount of bacterial mortality attributed to virus infection. Even with the presumed increase in bacterial mortality, the net increases in bacterial abundance in the samples that were enriched with active virus concentrate were higher than those seen in the controls. The viral abundance in bottles that were enriched with the active virus concentrate was significantly higher than that in the controls in Expts 2 and $3(p<0.05)$, but by the end of the experiments, viral abundances in the enriched incubations approached control levels. In Expts 1 and 2, rates of DOP hydrolysis were higher in the samples enriched with the active virus concentrate, and may have been due to an increase in the incidence of viral lysis. However, overall analysis of DCAA, DFAA, and DOP hydrolysis were quite variable and difficult to interpret. Results indicate that viral enrichment increased the incidence of bacterial infection and consequently stimulated the growth of subpopulations of non-infected heterotrophic bacterioplankton.
\end{abstract}

KEY WORDS: Virus Bacteria Infection - Dissolved organic matter

\section{INTRODUCTION}

Viruses are now known to be abundant throughout the world's oceans (e.g. Proctor et al. 1988, Bergh et al. 1989, Proctor \& Fuhrman 1990, Cochlan et al. 1993, Fuhrman \& Suttle 1993, Weinbauer \& Peduzzi 1994, Weinbauer et al. 1995, Noble \& Fuhrman 1998). Viruses can have a significant impact on the cycling of organic matter in the pelagic microbial food web as they are capable of contributing to as much as half of the heterotrophic bacterial mortality in coastal waters

\footnotetext{
•E-mail: noble@aludra.usc.edu
}

(Fuhrman \& Noble 1995). In contributing to the mortality of specific populations of bacterioplankton and phytoplankton by cell lysis and to the growth of noninfected cells, viruses exert both positive and negative controls over microbial communities. On the whole, viral infection of bacteria is thought to shift more production and respiration toward the bacteria, effectively creating a 'short circuit' of carbon flow between the bacterial, viral, and dissolved organic carbon (DOC) components (Bratbak et al. 1990, 1992, Proctor \& Fuhrman 1990, Fuhrman 1992).

Temporal variations in virus abundance and production have been observed in a few studies (e.g. Bratbak et al. 1990, Weinbauer et al. 1995) and have been 
found to vary widely under different conditions. Bratbak et al. (1990) suggested that short-term fluctuations in abundances of free viruses and planktonic bacteria indicated the importance of viruses in controlling bacterial growth. However, it was also suggested that many of the newly produced virus particles rapidly disintegrate upon release into seawater and do not go on to infect another host (Bratbak et al. 1990, 1992, 1994, 1996). Since numbers of viral particles are relatively constant in specific environments of the world's oceans (Wommack et al. 1992, Boehme et al. 1993, Cochlan et al. 1993, Steward et al. 1996), we might expect that where rates of viral production by lytic infection are relatively high, rates of viral degradation are also high (Steward et al. 1992, Weinbauer et al. 1995). Both production and loss processes are directly related to (but not limited to) the relative abundance of available host bacteria (Wilcox \& Fuhrman 1994), whether for lytic infection (production) or for degradation of virus particles by heat labile material and particles (loss) (Mitchell \& Jannasch. 1969, Noble 1998). Also, studies have shown that the loss of viral infectivity occurs at rates on the order of 1 to $20 \% \mathrm{~h}^{-1}$, that different rates of decay of infectivity occur for different viruses, and that decay is dependent upon the environmental and biochemical conditions of the water column (Suttle \& Chen 1992, Suttle et al. 1992, Suttle \& Chan 1993, Noble \& Fuhrman 1997).

Technically, there are multiple hurdles to overcome in estimating the direct effects of viral infection on the growth and survival of bacterioplankton in natural systems (Suttle 1994). First, culture-based studies, such as those described by Suttle \& Chen (1992), Suttle et al. (1992), Middelboe et al. (1996), and Noble \& Fuhrman (1997), are limited in their interpretation of processes occurring in natural systems due to the low proportion of the total bacteria in the ocean that are cultivatible (Staley \& Konopka 1985). Even if culture-based studies were possible for all virus-host systems, we would not be able to mimic the changing environmental conditions. Second, from a marine biogeochemical point of view, viruses are operationally defined as a component of the pool of dissolved organic matter (DOM), as most of them pass through a $0.45 \mu \mathrm{m}$ pore size filter and are often included in measurements of dissolved DNA (DDNA) (Paul et al. 1991, Børsheim 1993, Weinbauer et al. 1993). Successful lytic infection of bacterial host cells and subsequent cell lysis releases cell contents and newly made virus particles into the water column. These products of lytic infection, i.e. D-DNA, RNA, proteins, dissolved free amino acids (DFAA), dissolved combined amino acids (DCAA), carbohydrates, and intact virus particles are rich in $\mathrm{C}, \mathrm{N}$, and $\mathrm{P}$ and are usable by non-infected bacterioplankton for growth (Paul et al. 1989, Jørgensen et al. 1993, Jørgensen \&
Jacobsen 1996, Middelboe et al. 1996). Even though we can measure quantities of DOM that may originate from viral infection, it is still difficult to trace this material through the microbial food web. One way of determining virus-mediated effects is to increase the relative number of infectious particles in the seawater sample of interest, therefore increasing the number of potential encounters between virus and host.

Concentrates of the virus-sized fraction of seawater have been used previously to study the role of viruses in marine microbial communities (Proctor \& Fuhrman 1990, 1992, Suttle et al. 1990, Suttle 1992, Peduzzi \& Weinbauer 1993a, Weinbauer \& Peduzzi 1995). Suttle et al. (1990) showed that when particles ranging from 2 to $200 \mathrm{~nm}$ were concentrated from seawater samples and then added back into fresh seawater, primary production was reduced by as much as $78 \%$. Studies such as this, and one by Bratbak et al. (1993), have focused upon the importance of viruses in controlling algal populations, but have speculated that other substances in the concentrates might be responsible for some of the effects. Experimental studies of the complex nature of bacteria-virus interactions, which involve both the fate of the viral matter and the impacts of viruses on bacterial mortality and growth and nutrient cycling, have also been performed (Proctor \& Fuhrman 1992, Weinbauer \& Peduzzi 1995, Middelboe et al. 1996). Here, we have used natural viral populations concentrated from seawater to moderately increase the virus concentrations in protist-free seawater samples. By filtering to remove protists from the seawater, we eliminated the loss factor of heterotrophic bacteria due to grazing, which is a significant component of the bacterial mortality (McManus \& Fuhrman 1988, Pace 1988, Fuhrman \& Noble 1995), and focused directly upon the effects of viral infection. We observed changes in the frequency of visibly infected bacteria (FVIB) and bacterial abundance while minimally perturbing the system. In addition, we have measured the uptake and concentrations of seawater components such as DFAA, DCAA, and dissolved organic phosphate (DOP) to provide estimates of turnover in the heterotrophic bacterioplankton. This is the first study of this type that has incorporated not just an active enrichment and a control, but also an autoclaved enrichment to assess the difference between enriching with active infectious viruses versus heat inactivated virus material.

\section{MATERIALS AND METHODS}

Sample collection and concentration. Samples were collected in an acid-rinsed bucket, from Santa Monica Pier, CA, USA (3405' N, $11830^{\prime} \mathrm{W}$ ), transported to the University of Southern California, and processed 
within 30 min. All 3 experiments were performed in February 1995.

To make a virus concentrate, 801 of seawater was serially pressure filtered through $142 \mathrm{~mm}$ diameter Gelman A/E and $142 \mathrm{~mm}$ diameter $0.22 \mu \mathrm{m}$ pore size Millipore filters. Both filters were mounted in stainless steel filter holders which were attached to a 40 l stainless steel pressure filtration vessel $(<100 \mathrm{kPa})$. The filtrate was ultraconcentrated with a $30 \mathrm{kD}$ molecular weight cut-off spiral cartridge concentration unit (SY130, Amicon, Inc.). The final volume of the spiral cartridge concentrate was ca $200 \mathrm{ml}$, and was further concentrated to ca $20 \mathrm{ml}$ with Centriprep 30 concentration units (Amicon, Inc.). A small portion of this high molecular weight concentrate (HMWC) was retained and fixed with $2 \%$ formalin (final conc.) and stored at $4^{\circ} \mathrm{C}$ for analysis by transmission electron microscopy (TEM). Half of the remaining HMWC material was autoclaved for $25 \mathrm{~min}$ to inactivate the virus particles (referred to as AHMWC). Ultrafiltrate, which was used for the control addition (referred to as UF control), was $0.02 \mu \mathrm{m}$ filtered permeate from the spiral cartridge concentration system.

Seawater to be used for the experiment was taken from the same location at the same time, and stored at ambient seawater temperature until $1 \mathrm{~h}$ before the start of the experiment. At this time, the seawater was gravity filtered, first through a $47 \mathrm{~mm}$ Gelman $\mathrm{A} / \mathrm{E}$ glass fiber filter and then through a $47 \mathrm{~mm}, 0.6 \mu \mathrm{m}$ pore size Nuclepore filter, to remove protists. The filtrate and the incubations were subsequently spot checked for the presence and growth of protists; none were found. To ensure that the filtered seawater for the incubations was homogenous, the filtrate was collected in 1 large container and then equally distributed into 21 polycarbonate Nalgene sample containers.
The general experimental design involved incubations of the $0.6 \mu \mathrm{m}$ filtered seawater with additions of either UF control seawater, AHMWC, or HMWC. In the first experiment, there were the following 4 treatments: (1) an UF control (at the same volume as the 2fold HMWC), (2) 2-fold enrichment with HMWC, (3) 5 fold enrichment with HMWC, or (4) 2-fold enrichment with AHMWC (autoclaved material added at the same volume as the 2-fold HMWC enrichment, see Table 1). By knowing the original virus concentration of the seawater, the concentration factor, and with an assumed $50 \%$ recovery of virus particles, volumes of virus concentrate were added to approximate the 2 - and 5 -fold enrichments. The first experiment was a preliminary examination of the effects of the treatments and error within the methods, as the treatments were not replicated. Because there was not an apparent difference between the results with the 2- and 5-fold HMWC enrichments in the first experiment, and because our attempt was to minimally perturb the system, the second and third experiments involved 3 treatments in replicate bottles: $0.6 \mu \mathrm{m}$ filtered seawater to which was added (1) an UF control, (2) 2-fold HMWC enrichment or (3) 2-fold AHMWC enrichment (Table 1). Subsamples for all measurements were taken by pouring into sterile sample tubes.

Virus and bacterial counts. Viruses and bacteria were counted by ultracentrifugation $(120000 \times \mathrm{g}, 3 \mathrm{~h}$, $20^{\circ} \mathrm{C}$ ) of $4 \mathrm{ml}$ seawater samples (2\% formalin-preserved) onto carbon stabilized Formvar-coated 200 mesh copper grids (Ted Pella, Inc.) (Børsheim et al. 1990, Cochlan et al. 1993). Grids were then stained with $1 \%$ uranyl acetate for $30 \mathrm{~s}$. Viruses and bacteria were enumerated on a JEOL 100 CXII TEM. Taper corrections were implemented into the final calculations (Mathews \& Buthala 1970, Suttle 1993). Viruses and

Table 1. Abundances $( \pm S D$ ) of viruses and bacteria and concentrations of the dissolved organic matter (DOM) compounds measured in high molecular weight concentrate (HMWC) enriched, autoclaved HMWC (AHMWC) enriched and ultrafiltrate (UF) control incubations in 3 experiments immediately following enrichment. VA: viral abundance $(\mathrm{n}=20)_{i}$ BA: bacterial abundance $(n=20)$; DFAA: dissolved free amino acids $(n=3)$; DCAA: dissolved combined amino acids $(n=3)$; DOP: dissolved organic phos phate $(\mathrm{n}=3) ; \mathrm{PO}_{4}$ : total phosphate $(\mathrm{n}=3)$

\begin{tabular}{|c|c|c|c|c|c|c|c|c|}
\hline Expt & Treatment & $\begin{array}{c}\text { VA } \\
\left(10^{7} \mathrm{ml}^{-1}\right)\end{array}$ & $\begin{array}{c}\text { BA } \\
\left(10^{6} \mathrm{ml}^{-1}\right)\end{array}$ & $\begin{array}{l}\text { DFAA } \\
\text { (nM) }\end{array}$ & $\begin{array}{c}\text { DCAA } \\
\text { (nM) }\end{array}$ & $\begin{array}{l}\text { DOP } \\
(\mathrm{nM})\end{array}$ & $\begin{array}{c}\mathrm{PO}_{4} \\
(\mathrm{nM})\end{array}$ & $\begin{array}{c}\text { Temp } \\
\left({ }^{\circ} \mathrm{C}\right)\end{array}$ \\
\hline 1 & $\begin{array}{l}\text { UF control } \\
\text { 2-fold AHMWC } \\
\text { 2-fold HMWC } \\
\text { 5-fold HMWC }\end{array}$ & $\begin{array}{l}1.0(0.07) \\
1.3(0.19) \\
3.1(0.09) \\
5.5(0.77)\end{array}$ & $\begin{array}{l}1.2(0.13) \\
1.4(0.05) \\
1.5(0.05) \\
1.0(0.24)\end{array}$ & $\begin{array}{l}126(10) \\
138(4) \\
136(13) \\
165(13)\end{array}$ & $\begin{array}{l}303(39) \\
291(52) \\
284(30) \\
215(91)\end{array}$ & $\begin{array}{l}269(142) \\
525(87) \\
129(116) \\
260(130)\end{array}$ & $\begin{array}{l}608(267) \\
462(122) \\
535(195) \\
413(73)\end{array}$ & 17.2 \\
\hline 2 & $\begin{array}{l}\text { UF control } \\
2 \text {-fold AHMWC } \\
\text { 2-fold HMWC }\end{array}$ & $\begin{array}{l}0.79(0.03) \\
0.85(0.02) \\
1.7(0.1)\end{array}$ & $\begin{array}{l}1.04(0.01) \\
1.18(.06) \\
0.96(0.14)\end{array}$ & $\begin{array}{l}135(26) \\
106(6) \\
102(7)\end{array}$ & $\begin{array}{l}395(6) \\
374(27) \\
440(41)\end{array}$ & $\begin{array}{l}796(522) \\
320(155) \\
974(96)\end{array}$ & $\begin{array}{l}170(6) \\
246(27) \\
164(27)\end{array}$ & 16.5 \\
\hline 3 & $\begin{array}{l}\text { UF control } \\
\text { 2-fold AHMWC } \\
\text { 2-fold HMWC }\end{array}$ & $\begin{array}{l}0.96(0.02) \\
1.1(0.05) \\
2.2(0.1)\end{array}$ & $\begin{array}{l}1.2(0.1) \\
1.4(0.05) \\
1.3(0.1)\end{array}$ & $\begin{array}{c}210(14) \\
73(1) \\
90(7)\end{array}$ & $\begin{array}{l}689(82) \\
524(36) \\
705(8)\end{array}$ & $\begin{array}{l}527(73) \\
843(27) \\
547(189)\end{array}$ & $\begin{array}{l}329(13) \\
371(24) \\
342(26)\end{array}$ & 17.0 \\
\hline
\end{tabular}


bacteria were counted on quadruplicate grids at $27000 \times$ and $10000 \times(80 \mathrm{keV})$, respectively. More than 200 cells or viruses were counted per grid. Each HMWC was examined by adding $50 \mu \mathrm{l}$ of the concentrate to $3.95 \mathrm{ml}$ of $0.02 \mu \mathrm{m}$ filtered seawater, and following the method outlined above.

The FVIB was determined by looking through bacterial cells at higher accelerating voltage $(100 \mathrm{keV})$, and observing virus-shaped particles within bacteria, as described by Weinbauer et al. (1993). Only those bacteria which were stained lightly enough to enable some visualization of the cell's interior were considered for counting. Bacteria were counted as infected if they contained 5 or more virus-like particles. More than 500 bacterial cells were counted for each sample. Quadruplicate grids were counted to determine an average value of FVIB. Average values are reported with the standard deviations of quadruplicate counts.

Acridine orange direct counts (AODC) of bacteria (Hobbie et al. 1977) were also performed for each sample by filtering formalin-preserved $2 \%$ final concentration) seawater samples onto black $0.2 \mu \mathrm{m}$ pore size filters (Nuclepore), and staining with $0.1 \%(\mathrm{w} / \mathrm{v})$ acridine orange. Slides were counted by epifluorescence microscopy under green excitation with an Olympus Vanox microscope.

For consistency, bacterial abundances reported in this paper were determined by TEM using the same grids from which the virus counts and FVIB determinations were made. The total proportion of the bacterial population which was infected was calculated using the FVIB numbers and the total bacterial abundances as determined by TEM. The ratio of AODC to TEM bacterial counts was determined for each experiment and was $0.94 \pm 0.1($ mean $\pm S D, n=8)$ in Expt 1, $0.99 \pm$ 0.06 in Expt 2, and $0.99 \pm 0.03$ in Expt 3. Net changes in bacterial abundance were estimated from TEM counts by point to point calculations of bacteria gain or loss over time, and are reported as cells $\mathrm{l}^{-1} \mathrm{~d}^{-1}$ Virus production was estimated using the \% FVIB, multiplied by a conversion factor of 5.0 (middle conversion factor reported by Weinbauer \& Peduzzi unpubl. for same method) to account for the total portion of the bacterial population which was infected at that time (since intact virus particles are only visible inside the cell a small fraction of the time), multiplied by the bacterial abundance and an average assumed burst size of 20 viruses produced per infected bacterial cell (Bratbak et al. 1992, Fuhrman \& Noble 1995, GuixaBoixareu et al. 1996)

Bacterial growth rates. The thymidine incorporation method was modified from Fuhrman \& Azam (1982). At each time point, duplicate $42 \mathrm{ml}$ samples and $1 \%$ formalin-killed controls were subsampled into well-rinsed sterile $50 \mathrm{ml}$ polypropylene tubes (VWR brand). Sam- ples were inoculated with $5 \mathrm{nM}\left({ }^{3} \mathrm{H}\right.$-methyl) thymidine (obtained from Dupont New England Nuclear). Subsamples were incubated in the lab at seawater temperature in a fluorescent-lighted (during daytime, dark at night) incubator. After $30 \mathrm{~min}$ incubations, duplicate $20 \mathrm{ml}$ samples from each tube were filtered through HAWP Millipore filters (mixed cellulose acetate and cellulose nitrate, $0.45 \mu \mathrm{m}$ nominal pore size) in cold stainless steel filtration funnels on a 10-place manifold (Hoefer Scientific), then filtration valves were closed and $2 \mathrm{ml}$ ice-cold $5 \%$ trichloroacetic acid (TCA) was added. After $2 \mathrm{~min}$, the TCA was filtered through and the filters and funnels were rinsed 3 times with $1 \mathrm{ml}$ of cold $5 \% \mathrm{TCA}$, then the funnels were removed and the edge of the filters was rinsed 3 times with $1 \mathrm{ml} 5 \%$ TCA. Filters were placed in a glass $20 \mathrm{ml}$ vial and $1 \mathrm{ml} 1 \mathrm{~N}$ $\mathrm{HCl}$ was added, followed by heating to $90-100^{\circ} \mathrm{C}$ in an oven for $1 \mathrm{~h}$ (to hydrolyze the nucleic acids). After the vials cooled, $5 \mathrm{ml}$ Ecoscint (National Diagnostics) was added and the samples were counted by liquid scintillation with dpm correction (Packard). Conversion factors used to calculate production from the moles of thymidine incorporated were the averages reported in Fuhrman \& Azam (1982) at $2 \times 10^{18}$ cells produced per mole thymidine incorporated. Results of these measurements indicated unexpected problems with isotope dilution in the enriched samples, and were deemed unusable. We used the bacterial abundance results to calculate the net gain or loss in the bacterial populations over time (see 'Virus and bacterial counts').

Amino acid assimilation. Assimilation of DFAA was determined by incubation of subsamples with a mixture of $\left[{ }^{3} \mathrm{H}\right]$-labeled amino acids (Amersham), specific activity of $\sim 50 \mathrm{Ci} \mathrm{mmol}^{-1}$. Two hundred nCi (corresponding to about $0.4 \mathrm{nM}$ amino acids) was added to $10 \mathrm{ml}$ triplicate subsamples and 1 killed control $(2 \%$ formalin, final conc.) and incubated for 0.3 to $1 \mathrm{~h}$ (this allowed uptake of ca $10 \%$ of the added tracer). The incubations were stopped with $2 \%$ formalin (final conc.). Samples were filtered onto $0.2 \mu \mathrm{m}$ cellulose nitrate filters (Whatman), rinsed 3 times with Milli-Q water (Millipore) and radioassayed by liquid scintillation counting (LSC). Respiration of $\left[{ }^{3} \mathrm{H}\right]$-labeled amino acids during the incubation was assumed to be $50 \%$ of the assimilation (Middelboe et al. 1995).

Turnover of DCAA and DOP was estimated by the use of the fluorogenic substrate analog L-leucine-4methyl-coumarinylamide hydrochloride (Leu-MCA) and 4-methylumbelliferyl phosphate (MUF-P), respectively (Middelboe et al. 1995, 1996). Triplicate $1 \mathrm{ml}$ subsamples were incubated with $500 \mathrm{nM}$ Leu-MCA or $500 \mathrm{nM}$ MUF-P (final conc.) for 2 to $8 \mathrm{~h}$, and the turnover rate of the substrates was calculated from the increase in fluorescence caused by the enzymatic hydrolysis of the non-fluorescent substrates to the 
highly fluorescent products 7-amino-4-methyl-coumarin (AMC) and 4-methylumbelliferone (MUF). It is uncertain as to whether these additions represent additions at a tracer level. The increase in fluorescence was linear with time for the incubation times used. Background fluorescence at time zero was measured for each triplicate sample. A Spectrovision FD 200 (Chelmsford, MA, USA) fluorometer was used for the fluorescence measurements. Total DCAA hydrolysis was estimated from the concurrent measurement of the rate of Leu-MCA turnover and the actual concentration of DCAA. Likewise, total DOP hydrolysis was estimated from measurements of MUF-P turnover and DOP concentrations. The calculated hydrolysis of DCAA and DOP, thus, provide an estimate of the actual DCAA and DOP hydrolysis based upon the turnover rate of labeled substrate and the concentration of total substrate at each time point. The estimates of total DCAA and DOP hydrolysis during the whole incubation (integrated over the incubation period) are presented for each treatment (Table 3). It should be noted, however, that these estimates can only be considered as rough approximations of the actual hydrolysis rates. Since the addition of $500 \mathrm{nM}$ Leu-MCA and MUF-P caused a 2- to 4-fold increase in the actual concentration of DCAA and DOP (Table 1) the estimated rates may represent an overestimation of the actual hydrolysis of substrate. Consequently, variations in the natural substrate concentrations during the incubation may affect the degree of saturation of the enzymes with artificial substrate, and therefore the measured rates. However, assuming that net changes in natural substrate concentration are small relative to the bulk concentration, it is reasonable to believe that the estimated values are comparable within each experiment, although the values of DCAA and DOP turnover may not represent the actual hydrolysis rates.
Chemical analysis. For measurements of DFAA, DCAA, and DOP concentration, triplicate subsamples of $50 \mathrm{ml}$ were filtered through $0.2 \mu \mathrm{m}$ sterile filters (Sartorius, Inc.) and stored frozen. Concentrations of DFAA were measured by high performance liquid chromatography (HPLC) and pre-column derivatization with o-phthaldialdehyde (Lindroth \& Mopper 1979, Jørgensen et al. 1993). For measurements of DCAA, $1 \mathrm{ml}$ subsamples were freeze-dried and hydrolyzed in vapor phase under nitrogen atmosphere for $20 \mathrm{~min}$ at $150^{\circ} \mathrm{C}$ by a microwave technique (Jørgensen \& Jensen 1997). The hydrolyzed material was redissolved in borate buffer at $\mathrm{pH}>10$ to obtain optimal o-phthaldialdehyde reaction, and the total amino acid concentration in the sample was quantified by HPLC. For measurements of the concentration of total dissolved phosphorus, $125 \mathrm{mg}$ potassium peroxydisulfate was added to $10 \mathrm{ml}$ subsamples and autoclaved $\left(121^{\circ} \mathrm{C}, 45 \mathrm{~min}\right)$ to hydrolyze the organic $\mathrm{P}$ to $\mathrm{PO}_{4}$ (Koroleff 1968). The phosphate concentration was then measured photometrically by standard procedures (Strickland \& Parsons 1972). The DOP concentration was calculated by subtraction of $\mathrm{PO}_{4}$ concentrations in the untreated samples from the $\mathrm{PO}_{4}$ concentration in the hydrolyzed samples.

Statistical analyses. Analyses of results in Expt 1 allowed a preliminary examination of the differences between the treatment bottles, and the use of different methods. Analyses of results between treatment bottles in Expts 2 and 3 were performed using a repeated measures ANOVA with the use of Sigma Statistical software. To isolate the group or groups that were different from the others, the authors used a multiple comparison procedure called the Student-Newman-Keuls Method. All results reported as 'statistically significant' reflect $p$ $<0.05$. Results for FVIB in Table 2 are mean values over the entire duration of the experiments.

Table 2. Observed values of frequency of visibly infected bacteria (FVIB) in 3 experiments, mean \pm SD (Expts 1 and $2, n=7$; Expt $3, n=6)$, values averaged over the course of each of the 3 experiments. Estimate net bacterial production calculated from bacterial abundance data over the entire experiment. Estimated virus production calculated using FVIB values, and an estimated burst size of 20 . nd: not determined

\begin{tabular}{|c|c|c|c|c|}
\hline Expt & Treatment & Mean FVIB $(\% \pm$ SD) & $\begin{array}{c}\text { Estimated net bacterial } \\
\text { production }\left(\times 10^{8} \text { cell } \mathrm{l}^{-1} \mathrm{~d}^{-1}\right)\end{array}$ & $\begin{array}{c}\text { Estimated virus } \\
\text { production }\left(\times 10^{9} \text { virus } \mathrm{I}^{-1} \mathrm{~d}^{-1}\right)\end{array}$ \\
\hline 1 & $\begin{array}{l}\text { UF control } \\
\text { 2-fold AHMWC } \\
\text { 2-fold HMWC } \\
\text { 5-fold HMWC }\end{array}$ & $\begin{array}{l}1.43 \pm 0.30 \\
1.53 \pm 0.30 \\
2.82 \pm 0.35 \\
2.61 \pm 0.33\end{array}$ & $\begin{array}{c}6.77 \\
8.66 \\
7.34 \\
35.2\end{array}$ & $\begin{array}{l}1.04 \\
1.32 \\
2.07 \\
9.23\end{array}$ \\
\hline 2 & $\begin{array}{l}\text { UF control } \\
\text { 2-fold AHMWC } \\
\text { 2-fold HMWC }\end{array}$ & $\begin{array}{l}1.51 \pm 0.32 \\
1.86 \pm 0.31 \\
3.85 \pm 0.86\end{array}$ & $\begin{array}{c}9.99 \\
3.56 \\
15.9\end{array}$ & $\begin{array}{l}1.51 \\
0.66 \\
6.12\end{array}$ \\
\hline 3 & $\begin{array}{l}\text { UF control } \\
\text { 2-fold AHMWC } \\
\text { 2-fold HMWC }\end{array}$ & $\begin{array}{l}1.92 \pm 0.36 \\
2.47 \pm 0.16 \\
3.32 \pm 0.85\end{array}$ & $\begin{array}{c}-1.0 \\
3.48 \\
17.1\end{array}$ & $\begin{array}{c}\text { nd } \\
0.86 \\
5.67\end{array}$ \\
\hline
\end{tabular}




\section{RESULTS}

Santa Monica Bay, CA, is a mesotrophic system characterized by surface coastal water temperatures that range between 14 and $23^{\circ} \mathrm{C}$, chlorophyll a concentrations that typically range from 1 to $5 \mathrm{\mu g} \mathrm{l}^{-1}$, and rates of primary production that range from 0.411 to $1.254 \mathrm{~g} \mathrm{C}$ $\mathrm{m}^{-2} \mathrm{~d}^{-1}$ (Small et al. 1989). Viral and bacterial abundances in the coastal waters of Santa Monica Bay typi-
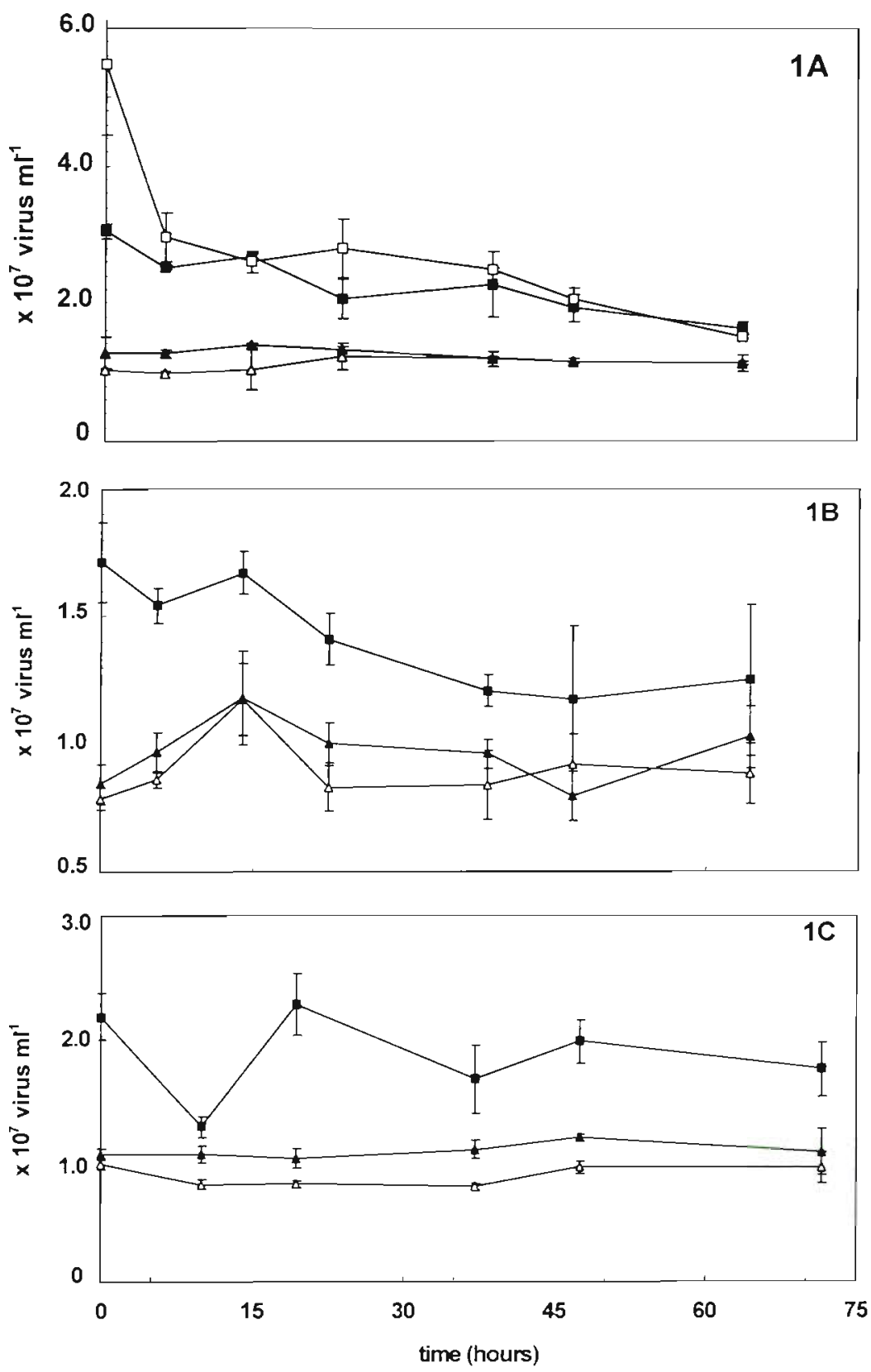

Fig. 1. Changes in viral abundance over time in Expts 1 (A), 2 (B), and 3 (C). ( $\triangle$ ) Ultrafiltrate (UF) control; ( 2 -fold high molecular weight concentrate (HMWC) enriched; (a) 5-fold HMWC enriched; (4) 2-fold autoclaved HMWC (AHMWC) enriched cally range from 1 to $7 \times 10^{7}$ and 0.8 to $6 \times 10^{6} \mathrm{ml}^{-1}$. respectively (Noble 1998).

\section{Viral abundance}

In all 3 experiments, the virus abundance at $0 \mathrm{~h}$ reflected the expected enrichments (Fig. 1A,B,C). The first experiment was performed by enriching seawater with either HMWC, which approximated 2- and 5-fold increases in virus abundance, AHMWC, or UF control (Table 1). Virus counts at $0 \mathrm{~h}$ reflected that the attempted 5-fold enrichment in Expt 1 caused an actual increase in viral abundance by a factor of 5.5 . In all 3 experiments, the 2 -fold enrichments increased the actual virus abundance by a range of factors from 2.2 to 3.1. Additionally, with the 5-fold HMWC enrichment, the results were not obviously different from the 2fold enrichment. Subsequently, Expts 2 and 3 involved only 2 -fold HMWC enrichments (Table 1)

In the first experiment, measurements of virus abundance suggested differences between the enriched and control treatment bottles. In Expts 2 and 3, virus abundances were significantly higher in the HMWC-enriched samples compared to the UF control and the AHMWC-enriched samples $(\mathrm{p}<0.05)$. Autoclaving of the HMWC appears to structurally destroy virus particles because the virus abundances in the AHMWC-enriched samples were similar to those in the UF controls in all 3 experiments (Fig. 1A,B,C).

In Expt 1, virus abundances in the 2and the 5-fold HMWC-enriched samples dropped over the time course to near control levels (Fig. 1A). In Expt 3, virus abundances demonstrated a drastic drop to near control levels within about $10 \mathrm{~h}$, to only $1 / 3$ of their abundance at time 0 (Fig. 1C). The dramatic decline in viral numbers may be from adsorption of a major fraction of the viruses to bacterial host cells, possibly indicating the initiation of infection, as the FVIB was at one of the highest points of any of the 3 experiments at $20 \mathrm{~h}$ at $4.6 \%$. It is possible that the concentrated virus material was clumped and/or sticky, thus making it more susceptible to adsorption onto particles and surfaces. However, the resulting 
rebound in virus numbers to the original levels in the HMWC incubation suggests that virus infection occurred to replenish the viral numbers.

\section{Frequency of visibly infected bacteria}

In the first experiment, the results suggested measurable differences between the FVIB in the HMWCenriched versus the control treatment bottles. In Expts 2 and 3, in samples enriched with active HMWC, the FVIB was significantly higher than in the UF control incubations (Fig. 2A,B,C). In Expts 1 and 2, the average FVIB was significantly greater in the HMWC-enriched samples than in the AHMWC-enriched samples ( $p<0.05$, Table 2). In the HMWC-enriched incubations in Expt 1, the FVIB increased consistently over time. In Expt 2, the mean FVIB in the HMWC-enriched samples was twice that in the UF control and the AHMWCenriched samples (Table 2). At the end of Expt 2, the FVIB was $5.1 \%$, the highest single point of any of the 3 experiments (Fig. 2B). Another peak in the FVIB occurred in Expt 3 with $4.6 \%$ of the bacterial population visibly infected (Fig. 2C).

\section{Bacterial results}

Bacterial abundances in the HMWCenriched samples demonstrated a net increase over the time course of all 3 experiments (Fig. 3A,B,C). In Expt 3, the bacterial abundances were significantly higher in the HMWC-enriched bottles than in the UF control and AHMWC-enriched bottles ( $p<0.05$, Fig. 3C). In the HMWC-enriched incubations in Expt 1, bacterial abundances demonstrated a net increase over the time course as they increased by $100 \%$, starting at ca $1.0 \times 10^{6}$ bacteria $\mathrm{ml}^{-1}$ at $0 \mathrm{~h}$, and ending at ca $2.0 \times 10^{6}$ bacteria $\mathrm{ml}^{-1}$ at $60 \mathrm{~h}$ (Fig. 3A). In Expt 3, the bacterial abundance in the HMWC-enriched samples increased

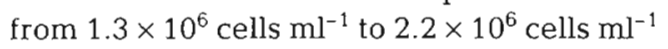
over $70 \mathrm{~h}$, whereas there was no visible increase in the bacterial abundance in the control and the AHMWC-enriched bottles (Fig. 3C).

The net change in bacterial abundance in the HMWC-enriched bottles was greater than that in the UF control in all 3 experi- ments (Table 2). The estimated net bacterial production in the HMWC-enriched incubation in Expt 2 was approximately 2 and 4 times that seen in the UF control and the AHMWC-enriched incubations, respectively (Table 2). Estimated net bacterial production in Expt 3 for the HMWC-enriched bottles was $17.1 \times 10^{8}{\text { cells } l^{-1}}^{-1}$ $\mathrm{d}^{-1}$, and $3.48 \times 10^{8}$ and $-1.0 \times 10^{8}$ cells $\mathrm{l}^{-1} \mathrm{~d}^{-1}$ for the AHMWC-enriched and the UF control bottles, respectively (Table 2).
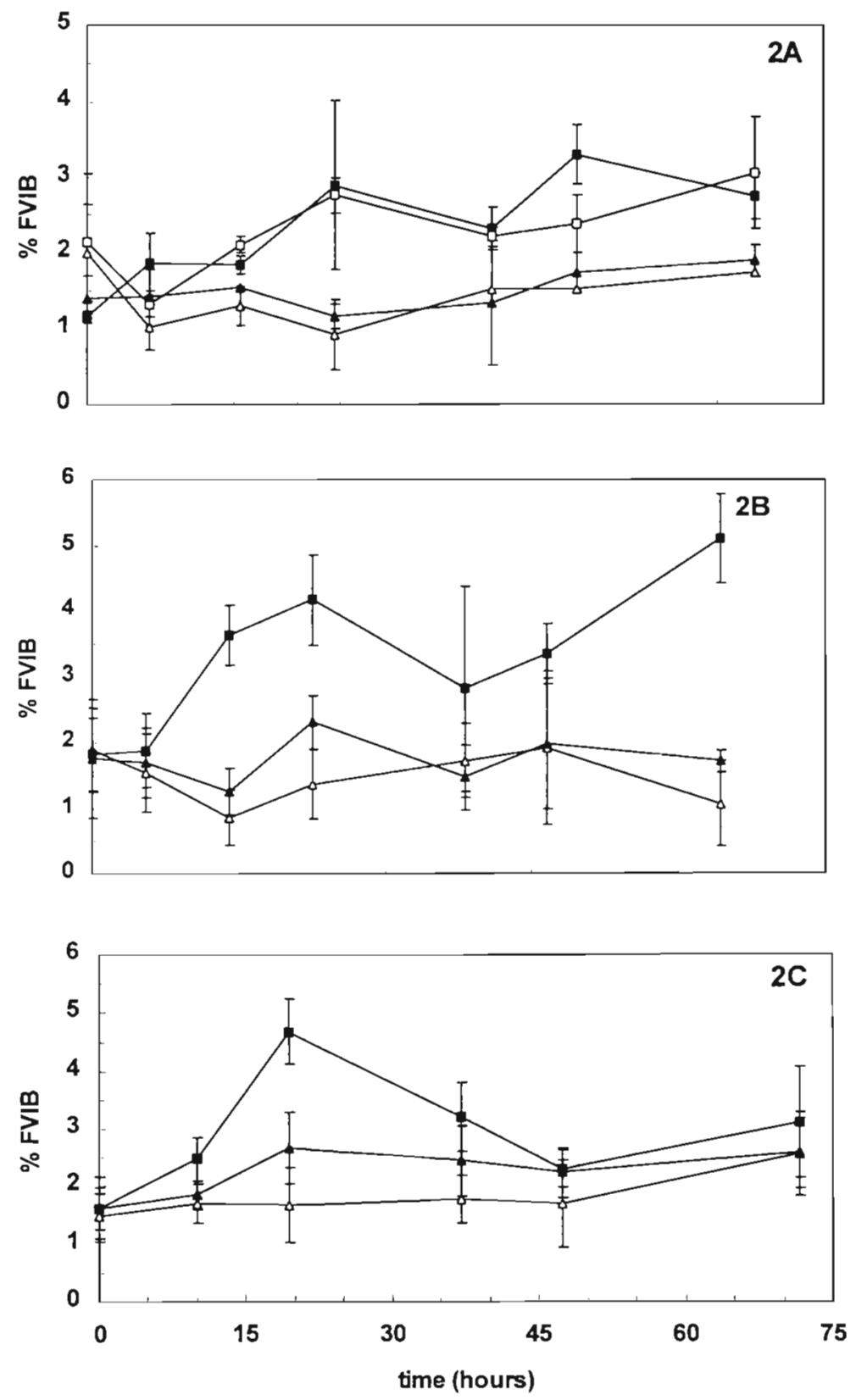

Fig. 2. Changes in the $\%$ of visibly infected bacteria (\% FVIB) over time in Expts 1 (A), 2 (B), and 3 (C). ( $\Delta$ ) UF control; ( $(\square)$ 2-fold HMWC enriched; (ㅁ) 5-fold HMWC enriched; (A) 2-fold AHMWC enriched 


\section{Enzyme activity}

Initial measurements of DFAA, DCAA, and DOP concentrations and assimilation rates in all 3 experiments demonstrated that the enrichments did not result in significant changes in the parameters which we measured as compared to the AHMWC-enriched or the UF control bottles. This suggests that the virus concentration was the only parameter which was measured that significantly changed due to enrichment (Table 1).
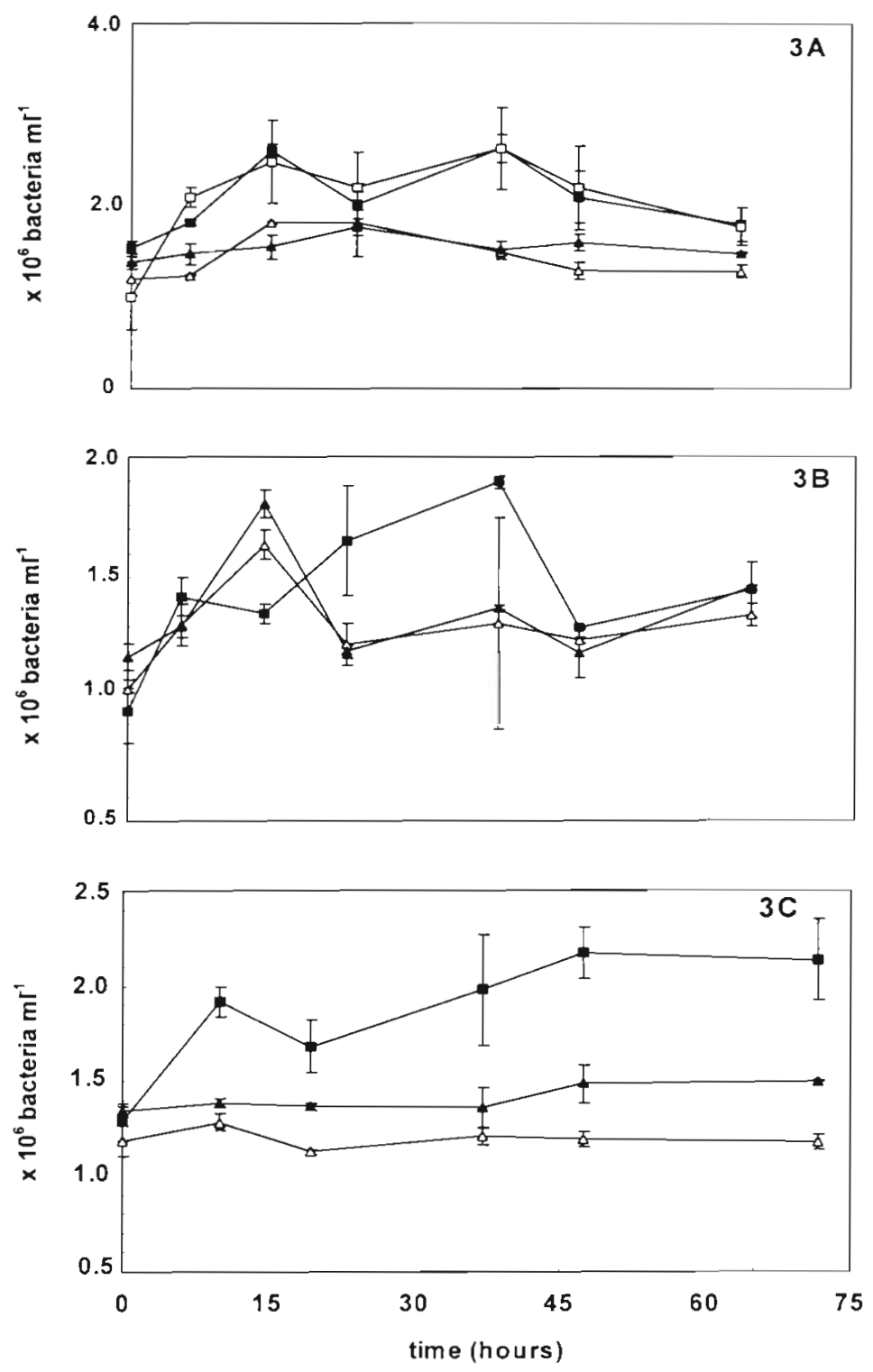

Fig. 3. Changes in bacterial abundance over time in Expts 1 (A), 2

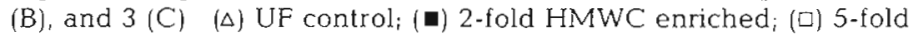
HMWC enriched; (4) 2 -fold AHMWC enriched. Error bars represent standard deviations calculated from quadruplicate counts; where they are not shown they are less than the width of the symbols
In Expt 1, the total DOP hydrolysis increased linearly with the HMWC enrichment, and the active 2and 5-fold enriched incubations demonstrated total hydrolysis nearly 3 and 6 times greater than that in the 2-fold AHMWC-enriched sample, respectively (Table 3). Additionally, the rate of DOP hydrolysis in the AHMWC-enriched sample was 3 times that in the control bottle (Table 3). The DFAA uptake was higher in all of the HMWC-enriched bottles (including the AHMWC-enriched bottle) than in the control in Expt 1 (Table 3). However, the total DCAA hydrolysis was not obviously different between any of the bottles (Table 3 ).

In Expt 2, the total hydrolysis of DOP in the HMWC-enriched samples was about twice that in the AHMWC-enriched and UF control incubations (Table 3). There was no significant difference in DFAA uptake between the incubations, but the DCAA hydrolysis values were significantly greater in the HMWC-enriched bottles compared to those in the UF control bottles (Table 3). However, the results were extremely variable and difficult to interpret.

In Expt 3, DOP hydrolysis values were significantly greater in the AHMWC-enriched incubations than in the UF control and the HMWC incubations. DFAA uptake and DCAA hydrolysis values were extremely variable and not significantly different between incubations (Table 3).

\section{Bacterial mortality and virus production}

In order to estimate the bacterial mortality which results from viral infection, we have used a set of assumptions. From the average values for the portion of the bacterial population which was visibly infected (FVIB), we estimated the total number of infected bacteria by applying a conversion factor (Proctor \& Fuhrman 1992, Weinbauer et al. 1995, Steward et al. 1996, Weinbauer \& Suttle 1996) which takes into account that only during part of the virus infection cycle in bacteria can intact virus particles be seen. In Proctor et al. (1993), conversion factors of 3.70 to 7.14 were reported for using the method of thin sectioning bacterial cells. The range of conversion factors reported previously for the method which we used 'looking through cells' was 3.9 to 6.6 (Weinbauer \& Peduzzi unpubl. data). To estimate the total percentage of the bacterial community that is phage infected at a given time, we can use the formula. FIB $=$ FVIB $\times f$, where FIB is the estimated frequency of total infected bacteria after the correction factor is applied, and $f$ is the con- 
Table 3. Total hydrolysis of dissolved organic phosphorus (DOP), uptake of dissolved free amino acids (DFAA), and total hydrolysis of dissolved combined amino acids (DCAA) integrated over the period of the entire incubation (mean \pm standard deviation). Expt 1: $\mathrm{n}=3$; Expts 2 and $3: \mathrm{n}=2$

\begin{tabular}{|c|c|c|c|c|}
\hline & UF Control & $\begin{array}{c}\text { 2-fold AHMWC } \\
\text { (autoclaved control) }\end{array}$ & 2-fold HMWC & 5-fold HMWC \\
\hline \multicolumn{5}{|l|}{ Expt 1} \\
\hline DOP hydrolysis (nmol l-1) & $24.5 \pm 1.7$ & $132 \pm 12$ & $321 \pm 46$ & $558 \pm 54$ \\
\hline DFAA uptake $\left(\mu \mathrm{mol} \mathrm{l}{ }^{-1}\right)$ & $10.8 \pm 0.6$ & $14.6 \pm 0.9$ & $13.4 \pm 0.9$ & $13.7 \pm 0.8$ \\
\hline DCAA hydrolysis $\left(\mathrm{nmol}^{-1}\right)$ & $89.5 \pm 6.5$ & $110 \pm 5.0$ & $101 \pm 5.0$ & $109 \pm 6.0$ \\
\hline \multicolumn{5}{|l|}{ Expt 2} \\
\hline DOP hydrolysis (nmol l-1) & $49 \pm 12$ & $72 \pm 40$ & $174 \pm 49$ & \\
\hline DFAA uptake $\left(\mu \mathrm{mol} \mathrm{l}^{-1}\right)$ & $20.5 \pm 3.1$ & $29.9 \pm 3.2$ & $25.1 \pm 3.9$ & \\
\hline DCAA hydrolysis ( $\mathrm{nmol} \mathrm{l}^{-1}$ ) & $188 \pm 5.0$ & $247 \pm 22$ & $327 \pm 80$ & \\
\hline \multicolumn{5}{|l|}{ Expt 3} \\
\hline DOP hydrolysis (nmol $\mathrm{l}^{-1}$ ) & $68 \pm 31$ & $366 \pm 110$ & $160 \pm 10$ & \\
\hline DFAA uptake $\left(\mu \mathrm{mol} \mathrm{l}^{-1}\right)$ & $11.0 \pm 1.5$ & $5.72 \pm 0.76$ & $11.8 \pm 2.0$ & \\
\hline DCAA hydrolysis (nmol $\mathrm{l}^{-1}$ ) & $128 \pm 57$ & $245 \pm 26$ & $164 \pm 6.0$ & \\
\hline
\end{tabular}

version factor used. We used a middle conversion factor of 5.0. In the UF control samples, the calculated percent of the bacterial population which was phage infected ranged from 7.2 to $9.6 \%$; in the AHMWCenriched samples the range was 7.7 to $12.4 \%$, and in the HMWC-enriched samples from 13.1 to $19.3 \%$. These values fall well within the range of those reported in the literature (Suttle 1994). To estimate the total mortality of the bacterial population the percentage values reported above would simply be doubled to reflect that when bacteria undergo binary fission, only 1 daughter cell survives to divide again (Proctor \& Fuhrman 1990), e.g. in the HMWC-enriched samples 26.2 to $38.6 \%$ of the total mortality was attributable to viruses. To determine the rate of virus production we can use the FIB, an assumed burst size, and an estimate of the latent period, the doubling time (Proctor et al. 1993, Steward et al. 1996, Weinbauer \& Suttle 1996). The calculation would follow the form of: $V=$ FIB $/ D t \times v$, where $V=$ virus production, $\mathrm{FIB}=$ total infected bacteria, $D t=$ doubling time estimated using bacterial production values, and $v=$ burst size. In Proctor et al. (1993) a comparison was made between the latent period and the doubling time $(D t)$ of specific virus/host systems and it was determined that they were about equal, so the doubling time (usually about $1 \mathrm{~d})$ used in the calculation here is a representation of the latent period. Bacterial lysis resulting from infection of marine bacteria results in the production of 20 to 100 new viruses per event (referred to as the 'burst size', Bratbak et al. 1992, Weinbauer \& Suttle 1996). Here, the assumed value for $V$ will be 20 , based upon TEM observations, and a burst size of 20 was used in Fuhrman \& Noble (1995).

Estimates of virus production for the 3 experiments reveal that rates of virus production in the samples were in the same range as values reported previously for Southern California waters, ranging from about 0.7 to $9.2 \times 10^{9}$ virus $\mathrm{I}^{-1} \mathrm{~d}^{-1}$ (Steward et al. 1992). In enriched incubations, rates of virus production were 2 to 6 times those rates seen in unenriched incubations (Table 2).

\section{DISCUSSION}

We have demonstrated that addition of a virus concentrate to a natural seawater sample directly influenced the heterotrophic bacterial population. By enriching seawater samples to increase virus abundances to just 2 -fold over normal concentrations, we have been able to stimulate the incidence of infection in the heterotrophic bacterial population relative to controls.

There was no significant difference in viral abundance between the AHMWC-enriched samples and the UF control samples, indicating that some drastic physical breakdown of virus particles occurred during the autoclaving of the enrichments (Fig. 1A,B,C). It is likely that autoclaving denatures the protein coats of the concentrated marine viruses. Autoclaving the enrichment did not cause significant increases in concentrations of DFAA, DCAA, or DOP (Table 1), but may have caused increases in other parameters which were not measured. We chose autoclaving of the enrichment rather than alternative heat treatment as previous research by M. Karner (pers. comm.) demonstrated measurable extracellular enzyme activity in seawater even after boiling or microwaving for up to $10 \mathrm{~min}$.

We did not observe increases in viral abundances in the HMWC-enriched incubations as we might have expected from an increased incidence of bacterial 
infection. Virus numbers increased only once in the HMWC-enriched incubations, between the second and third time point in Expt 3. Also, near the end of each of the 3 experiments (about $3 \mathrm{~d}$ ), virus abundances in the HMWC-enriched incubations approached the abundances in the control incubations. The destruction rate of the viruses exceeded the production rate of the viruses. It is likely that the number and activity of host cells in the incubations that were enriched with the active virus concentrates was not high enough to balance virus production with the concomitant processes that cause viral decay. In the actively enriched incubations, bacteria and/or phytoplankton may have been responsible for increased production of enzymes that degrade viral proteins and nucleic acids. It has been suggested previously that healthy picoplankton are capable of exuding a mucus type substance to indirectly protect them from virus infection (Murray 1995), and it is also quite possible that viral enrichment triggers bacterial production of exoenzymes necessary for metabolism of degraded virus components. On the production side, it is also possible that many of the viruses added in the enrichments did not have a corresponding host in the seawater incubations and that the burst size of the bacteria in our incubations was quite small relative to reported burst sizes in cultured bacteria. Marine bacteria are often much smaller in seawater than their cultured counterparts are in the laboratory, and therefore the bacteria in seawater may produce much fewer phages per cell infection event. As mentioned previously, the burst size which we assumed (20 virus particles per lysed cell) is on the low end of some which have been reported in the past (Bratbak et al. 1992, Weinbauer \& Peduzzi 1994), but is relatively high to others that have been reported by Kokjohn et al. (1991), who argued that burst sizes were 5 to 7 phage per lysed cell in natural waters, and were 27 to 65 phage per cell in full medium. Our assumed value is between these reported values, is supported by TEM observations, and was used for bacterial mortality estimates in the same waters (Fuhrman \& Noble 1995). Of the newly produced virus particles, it is likely that few go on to infect yet another host, and most are probably degraded and used by heterotrophic bacteria as a growth substrate. For example, if we assume that virus production occurred at an average rate of about $1.5 \times 10^{5}$ virus $\mathrm{ml}^{-1} \mathrm{~h}^{-1}$ in the 2 -fold HMWC-enriched incubation in Expt 1 (Table 2), then the degradation/removal of virus particles would have occurred at a rate of $2.0 \%$ $\mathrm{h}^{-1}$ to result in the observed abundance. In the 5 -fold enriched incubation, using an estimated virus production of about $4 \times 10^{5} \mathrm{ml}^{-1} \mathrm{~h}^{-1}$, the average degradation rate would have been $3.4 \% \mathrm{~h}^{-1}$. These rates of removal of virus particles included processes of degradation (by enzymes and other bioactive molecules) and adsorption (onto bacterial cells, container walls and sticky macromolecules), and similar to rates of loss of infectivity and rates of degradation reported previously in the literature (ranges from about 1 to $20 \% \mathrm{~h}^{-1}$, e.g. Bratbak et al. 1990, 1992, Suttle \& Chen 1992, Suttle et al. 1992, Suttle \& Chan 1993, Wommack et al. 1996, Noble \& Fuhrman 1997, Noble 1998).

We were concerned that the concentration process might destroy the virus particles. However, by TEM analysis, our active HMWC appeared to contain intact and distinctly recognizable free virus particles, which were stained similarly to free viruses in the control samples. In addition, viruses were the most abundant particle type in the concentrates. Arguably, it is possible that we have added some inactivated viruses to our experiments and other heat-labile high molecular weight bioactive material as has been reported by Suttle et al. (1992). However, even though all of the virus particles in the HMWC enrichments may not have been infectious upon addition to the seawater samples, the resulting FVIB values indicate the likelihood that at least a portion of the viruses were infective.

Even though the enrichment of seawater with virus concentrate would be likely to directly increase the frequency of bacterial cells which are infected, it has been suggested in the past that this type of enrichment may induce lysogens in the bacterial populations into the lytic phase (Weinbauer \& Peduzzi 1995). Thus, in the enriched samples, if induction occurred we might have also observed a higher FVIB. However, if induction occurred in a major fraction of the bacterial population, we would have expected there to be a crash in the bacterial population, and an ensuing increase in viral numbers (Jiang \& Paul 1996), but neither occurred. It is possible that lysogens were induced in a small percentage of the population, but based on the work of Wilcox \& Fuhrman (1994) it is likely that the predominant mode of infection was lytic.

We also found that even with an increased viral abundance, which resulted in a subsequent increase in the FVIB, the total bacterial abundance also increased. Bacterial mortality due to virus infection is a process which is controlled mainly by the encounter rate between the virus and its host (Murray \& Jackson 1992). In this system, where protist-mediated bacterial mortality was eliminated, we increased the number of potential virus to bacteria encounters, and thus increased the incidence of viral infection. However, it appears that growth of the non-infected bacterial population was also stimulated. The net increases in bacterial abundance were greater in the HMWC-enriched samples than those in the control incubations (Table 2). This increase suggests that the growth rate of the bacterial population was higher than the mortality. These 
heightened rates of bacterial production may be the result of the use of lytic infection products as substrates for growth by non-infected bacteria (Lammers 1992, Middelboe et al. 1996). The growth of bacterial cells in the control incubations may have been limited by a nutrient that was otherwise found in sufficient amounts in the enriched incubations, or may have suffered from reduced host density, and a lower incidence of viral infection, due to the filtration to remove the protists. Alternatively, it has been previously speculated that the ultraconcentration process results in colloid aggregation and particle formation (Paul et al. 1991). Not only would this material not be detected in measurements of DCAA, DFAA, or DOP due to the fact that it is present in the greater than $0.2 \mu \mathrm{m}$ size fraction, but it would also be disrupted by autoclaving (Paul et al. 1991). It is possible that particle formation from the ultraconcentration process created a preferred growth substrate for bacteria in those incubations that were HMWC-enriched. The formation of particles could also provide surfaces for nutrient accumulation and create microzones that supported bacterial growth (Azam \& Ammerman 1984).

With these enrichment experiments, we might have expected an increase in the bacterial growth rate, but it is not completely obvious why the total bacterial abundance would increase. This type of increase has also been reported by Weinbauer \& Peduzzi (1995), Lammers (1992) and Peduzzi \& Weinbauer (1993b). It is possible that the non-infected cells that grow at the expense of the infected cells are smaller (have a lower carbon content), i.e. that biomass is not increasing as suggested in Middelboe et al. (1996). Previous reports, such as Middelboe et al. (1996) suggest that the bacterial growth efficiency of non-infected cells in a virusenriched incubation is lower than cells not subjected to virus enrichments. It may be that the input of labile viral lysates favors growth of some small, fast-growing bacteria. Lammers (1992) observed the same phenomenon, although he did not comment on why he found a net increase in the bacterial population in virus amended cultures when growing on the same substrate as the control population without viruses.

Even though our measurements of amino acid and phosphate hydrolysis were difficult to interpret, there is weak evidence that enrichment caused an increase in rates of hydrolysis of DOP and DCAA and rates of DFAA uptake (Table 3). There was not a demonstrated increase in the levels of DOP directly attributed to the enrichments, but in Expts 1 and 2, we demonstrated that enzymatic breakdown of organic $P$ was stimulated in seawater with active viral enrichments (Table 3 ). It is possible that these experiments behaved much like experiments reported by Zweifel et al. (1993), where the authors suggested that a P addition enhanced cell division. It has also been reported by Poindexter (1987) that $P$ availability regulates cell production rather than biomass production. An input of $\mathrm{P}$ from viral lysis or from enzyme enrichment in the HMWC-enriched bottles may have caused a similar enhancement of cell division and thus an increase in bacterial numbers, with a possible decrease in bacterial cell size. In Weinbauer \& Peduzzi (1995), arguments on the release and recycling of nutrients by bacteria were based upon net changes in concentrations which may not reveal some of the direct effects of viral infection. The autoclaved enrichments may also have been chemically altered, in which case the enrichments were different both in viral activity and chemical content. Alternatively, perhaps the HMWC-enriched incubations contained heightened concentrations of active, free extracellular enzymes, which hydrolyzed the DOM into more labile components that were taken up by heterotrophic bacteria, whereas in incubations that were enriched with AHWMC such enzymes were inactivated or destroyed by autoclaving. Free extracellular enzymatic activity is usually insignificant compared with the particle associated activity in marine waters, (e.g. Hoppe 1983, Rosso \& Azam 1987, Delmas et al. 1994), and the observed enzymatic activities were probably mainly associated with the bacteria.

Within this system, where protists have been removed, and where concentrations of viruses have been purposefully increased, there are discrepancies in production (growth and virus replication) measurements and loss (bacterial mortality and virus decay) measurements that indicate the effects of virus-mediated processes. We have focused upon the impact that natural virus populations have on natural bacterial assemblages, and have shown that as little as a 2 -fold increase in viral numbers is enough to affect the bacterial community. We have also demonstrated that an autoclaved virus enrichment does not elicit the same effects, indicating the likelihood that the results were due to viral infection processes and not just enrichment of seawater with available hydrolysable DOM. There is evidence from our experiments that viral activity increased both the levels of bacterial mortality and the total number of bacterial cells and we attribute this to heightened viral infection. Also, addition of virus concentrates to seawater might have influenced the composition of the bacterial community and consequently the degradation and transformation of DOM. Clearly, research on processes mediated by viruses indicates that they are not only important to bacterial and algal mortality (Fuhrman \& Suttle 1993, Suttle 1994, Fuhrman \& Noble 1995) but that they also play potentially important roles in the release and recycling of $\mathrm{C}, \mathrm{N}$ and $\mathrm{P}$ in the oceans (Weinbauer \& Peduzzi 1995, Middelboe et al. 1996). Continued advancements in 
methods to directly assess the rates of virus infection, virus production, and effects of viruses on bacterial mortality will permit a more complete understanding of the role of viruses in the 'microbial loop'.

Acknowledgements. We thank N. O. G. Jørgensen for assistance with the AA measurements. Work by M.M. was supported by the Danish Strategic Environmental Research Programme, the Carlsberg Foundation, the Beckett Foundation, and the Danish Pasteur Society. Research by R.T.N. was supported by NSF Grant \#OCE-9634028, the Danish Research Academy, the ARCS Foundation, and USC Sea Grant.

\section{LITERATURE CITED}

Azam F, Ammerman JW (1984) Flows of energy and nutrients in marine ecosystems. Plenum Press, New York

Bergh $\oslash$, Børsheim KY, Bratbak G, Heldal M (1989) High abundance of viruses found in aquatic environments. Nature 340:467-468

Boehme J, Frischer ME, Jiang SC, Kellogg CA, Pichard S, Rose JB, Steinway C, Paul JH (1993) Viruses, bacterioplankton, and phytoplankton in the southeastern Gulf of Mexico: distribution and contribution to oceanic DNA pools. Mar Ecol Prog Ser 97:1-10

Børsheim KY (1993) Native marine bacteriophages. FEMS Microbiol Ecol 102:141-159

Borsheim KY, Bratbak G, Heldal M (1990) Enumeration and biomass estimation of planktonic bacteria and viruses by transmission electron microscopy. Appl Environ Microbiol 56:352-356

Bratbak G, Heldal M, Norland S, Thingstad TF (1990) Viruses as partners in spring bloom microbial trophodynamics. Appl Environ Microbiol 56:1400-1405

Bratbak G, Heldal M, Thingstad TF, Riemann B, Haslund $\mathrm{OH}$ (1992) Incorporation of viruses into the budget of microbial C-transfer. A first approach. Mar Ecol Prog Ser 83:273-280

Bratbak G. Egge JK, Heldal M (1993) Viral mortality of the marine alga Emiliana huxleyi (Haptophyceae) and termination of algal blooms. Mar Ecol Prog Ser 93:39-48

Bratbak G, Thingstad F, Heldal M (1994) Viruses and the microbial loop. Microb Ecol 28:209-221

Bratbak G, Heldal M, Thingstad TF, Tuomi P (1996) Dynamics of virus abundance in coastal seawater FEMS Microbiol Ecol 19(4):263-269

Cochlan WP, Wikner J, Steward GF, Smith DC, Azam F (1993) Spatial distribution of viruses, bacteria and chlorophyll a in neritic, oceanic and estuarine environments. Mar Ecol Prog Ser 92:77-87

Delmas D, LeGrand C, Bechemin C, Collinot C (1994) Exoproteolytic activity determined by flow injection analysis: its potential importance for bacterial growth in coastal marine ponds. Aquat Living Resour 7:17-24

Fuhrman JA (1992) Bacterioplankton roles in cycling of organic matter the microbial food web. In: Falkowski PG, Woodhead AD (eds) Primary productivity and biogeochemical cycles in the sea. Plenum Press, New York, p 361-383

Fuhrman JA, Azam F (1982) Thymidine incorporation as a measure of heterotrophic bacterioplankton production in marine surface waters: evaluation and field results. Mar Biol 66:109-120

Fuhrman JA, Noble RT (1995) Viruses and protists cause similar bacterial mortality in coastal seawater. Limnol Oceanogr 40(7):1236-1242
Fuhrman JA, Suttle CA (1993) Viruses in marine planktonic systems. Oceanography 6:51-63

Guixa-Boixareu N, Calderon-Paz JI, Heldal M, Bratbak G, Pedros-Alio C (1996) Viral lysis and bacterivory as prokaryotic loss factors along a salinity gradient. Aquat Microb Ecol 11:215-227

Hobbie JE, Daley RJ, Jasper S (1977) Use of Nuclepore filters for counting bacteria by fluorescence microscopy. Appl Environ Microbiol 33:1225-1228

Hoppe HG (1983) Significance of exoenzymatic activities in the ecology of brackish water: measurements by means of methylumbelliferyl-substrates. Mar Ecol Prog Ser 11: 299-308

Jiang SC, Paul JH (1996) Occurrence of lysogenic bacteria in marine microbial communities as determined by prophage induction. Mar Ecol Prog Ser 142:27-38

Jørgensen NOG, Jacobsen CS (1996) Bacterial uptake and utilization of dissolved DNA. Aquat Microb Ecol 11 $263-270$

Jørgensen NOG, Jensen RE (1997) Determination of dissolved combined amino acids using microwave assisted hydrolysis and HPLC precolumn derivatization for labelling of primary and secondary amines. Mar Chem 57 $287-297$

Jørgensen NOG, Kroer N, Coffin RB, Yang XH, Lee C (1993) Dissolved free amino acids, combined amino acids, and DNA as sources of carbon and nitrogen to marine bacteria. Mar Ecol Prog Ser 98:135-148

Kokjohn TA, Sayler GS, Miller RV (1991) Attachment and replication of Pseudomonas aeruginosa bacteriophages under conditions simulating aquatic environments. J Gen Microbiol 137:661-666

Koroleff F (1968) Determination of total phosphorus in natural waters by means of persulfate oxidation. ICES Coun Meet $\mathrm{C} / 33: 209-212$

Lammers WT (1992) Stimulation of bacterial cytokinesis by bacteriophage predation. Mar Freshw Biol 235:261-265

Lindroth P, Mopper K (1979) High performance liquid chromatographic determinations of subpicomole amounts of amino acids by precolumn fluorescence derivatization with o-phthaldialdehyde. Anal Chem 51:1667-1674

Mathews J, Buthala DA (1970) Centrifugal sedimentation of virus particles for electron microscope counting. J Virol 5(5):598-603

McManus GB, Fuhrman JA (1988) Control of marine bacterioplankton populations: measurement and significance of grazing. Hydrobiologia 159:51-62

Middelboe M, Borch NH, Kirchman DL (1995) Bacterial utilization of dissolved free amino acids, dissolved combined amino acids, and ammonium in the Delaware Bay estuary effects of carbon and nitrogen limitation. Mar Ecol Prog Ser 128:109-120

Middelboe M, Jørgensen NOG, Kroer N (1996) Effects of viruses on nutrient turnover and growth efficiency of noninfected marine bacterioplankton. Appl Environ Microbiol 62:1991-1997

Mitchell R, Jannasch HW (1969) Processes controlling virus inactivation in seawater. Environ Sci Technol 3:941-945

Murray AG (1995) Phytoplankton exudation: exploitation of the microbial loop as a defence against algal viruses. J Plankton Res 17(5):1079-1094

Murray AG, Jackson GA (1992) Viral dynamics: a model of the effects of size, shape, motion and abundance of singlecelled planktonic organisms and other particles. Mar Ecol Prog Ser 89:103-116

Noble RT (1998) Fate of viruses in the marine environment. PhD thesis, University of Southern California, Los Angeles 
Noble RT, Fuhrman JA (1997) Virus decay and its causes in coastal waters Appl Environ Microbiol 63(1):77-83

Noble RT, Fuhrman JA (1998) Use of SYBR Green I for rapid epifluorescence counts of marine viruses and bacteria. Aquat Microb Ecol 14(2):113-118

Pace ML (1988) Bacterial mortality and the fate of bacterial production. Hydrobiologia 159:41-49

Paul JH, Jeffrey WH, David AW, DeFlaun MF, Cazares LH (1989) Turnover of extracellular DNA in eutrophic and oligotrophic environments of southwest Florida. Appl Environ Microbiol 55:1823-1828

Paul JH, Jiang SC, Rose JB (1991) Concentration of viruses and dissolved DNA from aquatic environments by vortex flow filtration. Appl Environ Microbiol 57(8):2197-2204

Peduzzi P, Weinbauer MG (1993a) Effect of concentrating the virus-rich $2-200 \mathrm{~nm}$ size fraction of seawater on the formation of algal flocs (marine snow). Limnol Oceanogr 38 : $1562-1565$

Peduzzi P, Weinbauer MG (1993b) The submicron size fraction of seawater containing high numbers of virus particles as bioactive agent in unicellular plankton community successions. J Plankton Res 15:1375-1386

Poindexter JS (1987) Bacterial response to nutrient limitation. In: Fletcher M, Gray TRG, Jones JG (eds) Ecology of microbial communities. Cambridge University Press, London, p 283-317

Proctor LM, Fuhrman JA (1990) Viral mortality of marine bacteria and cyanobacteria. Nature 343:60-62

Proctor LM, Fuhrman JA (1992) Mortality of marine bacteria in response to enrichments of the virus size fraction from seawater. Mar Ecol Prog Ser 87:283-293

Proctor LM, Fuhrman JA, Ledbetter MC (1988) Marine bacteriophages and bacterial mortality. EOS Trans Am Geophys Union 69:1111-1112

Proctor LM, Okubo A, Fuhrman JA (1993) Calibrating estimates of phage induced mortality in marine bacteria: ultrastructural studies of marine bacteriophage development from one-step growth experiments. Microb Ecol 25: 161-182

Rosso AL, Azam F (1987) Proteolytic activity in coastal oceanic waters: depth distribution and relationship to bacterial populations. Mar Ecol Prog Ser 41:231-240

Small LF, Landry MR, Eppley RW, Azam F, Carlucci AF (1989) Role of plankton in the carbon and nitrogen budgets of Santa Monica Basin, California. Mar Ecol Prog Ser 56: $57-74$

Staley JT, Konopka A (1985) Measurement of in situ activities of nonphotosynthetic microorganisms in aquatic and terrestrial habitats. Annu Rev Microbiol 39:321-346

Steward GF, Wikner J, Cochlan WP, Smith DC, Azam F (1992) Estimation of virus production in the sea: II. Field results. Mar Microb Food Webs 6(2):79-90

Steward GF, Smith DC, Azam F (1996) Abundance and production of bacteria and viruses in the Bering and Chukchi Sea. Mar Ecol Prog Ser 131:287-300

Strickland JDH, Parsons TR (1972) A practical handbook of

Editorial responsibility: Farooq Azam,

La Jolla, California, USA seawater analysis. Fish Res Board Canada, Ottawa

Suttle CA (1992) Inhibition of photosynthesis in phytoplankton by the submicron size fraction concentrated from seawater. Mar Ecol Prog Ser 87:105-112

Suttle CA (1993) Enumeration and isolation of marine viruses. In: Kemp PF, Sherr BF, Sherr EB, Cole JJ (eds) Current methods in aquatic microbial ecology. Lewis Publishing, Boca Raton, p 121-134

Suttle CA (1994) The significance of viruses to mortality in aquatic microbial communities. Microb Ecol 28:237-243

Suttle CA, Chan AM (1993) Marine cyanophages infecting oceanic and coastal strains of Synechococcus: abundance, morphology, cross-infectivity, and growth characteristics. Mar Ecol Prog Ser 92:99-109

Suttle CA, Chen F (1992) Mechanisms and rates of decay of marine viruses in seawater. Appl Environ Microbiol 58: $3721-3729$

Suttle CA, Chan AM, Cottrell MT (1990) Infection of phytoplankton by viruses and reduction of primary productivity. Nature 387:467-469

Suttle CA, Chen F, Chan AM (1992) Marine viruses: decay rates, diversity and ecological implications. In: Nash CC II (ed) International Marine Biotechnology Conference 'IMBC-91': short communications of the invited lectures ecology. W Brown Co, Dubuque, IA, p 153-163

Weinbauer MG, Peduzzi P (1994) Frequency, size, and distribution of bacteriophages in different marine bacterial morphotypes. Mar Ecol Prog Ser 108:11-20

Weinbauer MG, Peduzzi P (1995) Effect of virus-rich high molecular weight concentrates of seawater on the dynamics of dissolved amino acids and carbohydrates. Mar Ecol Prog Ser 127:245-253

Weinbauer MG, Suttle CA (1996) Potential significance of lysogeny to bacteriophage production and bacterial mortality in coastal waters of the Gulf-of-Mexico. Appl Environ Microbiol 62(12):4374-4380

Weinbauer MG, Fuks D, Peduzzi P (1993) Distribution of viruses and dissolved DNA along a coastal trophic gradient in the Northern Adriatic Sea. Appl Environ Microbiol 59(12):4074-4082

Weinbauer MG, Fuks D, Puskaric S, Peduzzi P (1995) Diel, seasonal, and depth-related variability of viruses and dissolved DNA in the Northern Adriatic Sea. Microb Ecol 30: $25-41$

Wilcox RM, Fuhrman JA (1994) Bacterial viruses in coastal seawater: lytic rather than lysogenic production. Mar Ecol Prog Ser 114:35-45

Wommack KE, Hill RT, Kessel M, Russek-Cohen E, Colwell RR (1992) Distribution of viruses in Chesapeake Bay. Appl Environ Microbiol 58:2965-2970

Wommack KE, Hill RT, Muller TA, Colwell RR (1996) Effects of sunlight on bacteriophage viability and structure. Appl Environ Microbiol 62(4): 1336-1341

Zweifel UL, Norrman B, Hagström $\AA$ (1993) Consumption of dissolved organic carbon by marine bacteria and demand for inorganic nutrients. Mar Ecol Prog Ser 101:23-32

Submitted: December 9, 1997; Accepted: September 22, 1998 Proofs received from author(s): July 6, 1999 